Journal of Animal and Veterinary Advances 9 (10): 1515-1518, 2010

ISSN: $1680-5593$

(C) Medwell Journals, 2010

\title{
The Presence of Teredo navalis Linnaeus, 1758 (Mollusca, Bivalvia, Teredinidae) in the Southern Black Sea, Turkey
}

\author{
Mehmet Culha \\ Department of Hydrobiology, Faculty of Fisheries, Canakkale Onsekiz Mart University, \\ Terzioglu Campus, 17100 Canakkale, Turkey
}

\begin{abstract}
A total of 35 specimens of boring bivalve, Teredo navalis was found during the benthic surveys conducted at a depth of between 0.5 and $5 \mathrm{~m}$ into some old tree roots and old wood pieces on stony-sand bottom in the southern Black Sea (Ayancik coasts of Sinop Province) of Turkey between 2006 and 2007. This species is new record for the Turkish Black Sea coast.
\end{abstract}

Key words: Teredo navalis, Ayancik coasts (Sinop), the Southern Black Sea, bivalve, Turkey

\section{INTRODUCTION}

The family, Teredinidae Rafinesque, 1815 (Bivalvia, Heterodonta) which includes the group of species known as Common shipworm or Naval shipworm (boring organisms) comprises five genera, namely Teredo Linne, 1758; Lyrodus Binney, 1870 ex Gould ms; Teredora Bartsch, 1921; Psiloteredo Bartsch, 1922 and Teredothyra Bartsch, 1921 (Clemam, 2009). This family is represented by fourteen species (i.e., Teredo bartschi Clapp 1923; Lyrodus bipartitus (Jeffreys 1860: Teredo); Bankia bipennata (Turton 1819: Teredo); Bankia carinata (Gray J.E. 1827: Teredo); Teredothyra excavata (Jeffreys 1860: Teredo); Bankia fimbriatula Moll and Roch 1931; Teredinidae incertaesedis (Provisory name); Teredora malleolus (Turton 1822: Teredo); Psiloteredo megotara (Hanley in Forbes and Hanley 1848: Teredo); Teredo navalis Linne 1758; Nototeredo norvagica (Spengler 1792: Teredo); Lyrodus pedicellatus (de Quatrefages1849: Teredo); Psiloteredosenegalensis (de Blainville 1824: Teredo); Spathoteredo spatha (Jeffreys 1860: Teredo)] in the Mediterranean according to Clemam (2009).

According to the existing literature, the distribution of the species in Turkey into two genuses was as follows: Teredo 1, Lyrodus 1 (Demir, 2003); Teredo 1, Nototeredo 1 (Ozturk and Cevik, 2000). In contrast to Turkey's coasts in the Mediterranean having five genuses were Teredo, Lyrodus, Teredora, Psiloteredo, Teredothyra (Clemam, 2009).

New data on the locality of Teredo navalis found in the Black Sea are provided by means of this study and the species is reported for the first time in Turkish waters of the Black Sea. The aim of this study is to contribute to the knowledge of the Mollusk biodiversity of Turkey.

\section{MATERIALS AND METHODS}

Samplings were carried out in the upper-infralittoral zone of Ayancik coasts (Sinop Peninsula) located in the central part of the southern Black Sea (Fig. 1). The samples were collected by using a spatula from some piece of wood and into tree roots and also throw out the species in old wood under the water at three region (FBC: $41^{\circ} 4643^{\prime \prime} \mathrm{N}, 34^{\circ} 36^{\prime} 10^{\prime \prime} \mathrm{E}$; AP: $41^{\circ} 5650^{\prime \prime} \mathrm{N}, 34^{\circ} 34^{\prime} 39^{\prime \prime} \mathrm{E}$; CB: $\left.41^{\circ} 5649^{\prime \prime} \mathrm{N}, 34^{\circ} 33^{\prime} 42^{\prime \prime} \mathrm{E}\right)$ : FPC in front of old forest process company, inner harbour (Ayancik village) in tree roots, 11.07.2006; AP- Ayancik port in wood pieces, 26.08.2006; CB Camurca beach in wood pieces, 07.10.2006 having depths of between 0.5 and $5 \mathrm{~m}$ on stony-sand bottom, during these period in order to determine the present status of macrofauna in the area (Culha et al., 2008). Since climatic conditions are most suitable for the bivalve larvae during these periods (Didziulis, 2007), the surveys were conducted during four seasons, mostly summer and autumn.

Relevant morphological and ecological characteristics of the boring organisms (Bivalve) were recorded and photographed in their natural habitats. Materials collected in the local area were fixed in formalin of $4 \%$ to be examined in the laboratory. Then, they were carried to the laboratory for further investigation. After removal of the specimens from wood, the material was washed through a sieve with 0.5 and $1 \mathrm{~mm}$ mesh size with the help of pressurized water and was then transferred into containers with alcohol of $70 \%$.

The specimens were identified by examining their macroscopic and microscopic features based on the studies of Hayward and Ryland (1990) and Didziulis (2007). For the taxonomic description of Teredo navalis L., 1758, references NIMPIS (2002), Ozturk and Cevik (2000), 


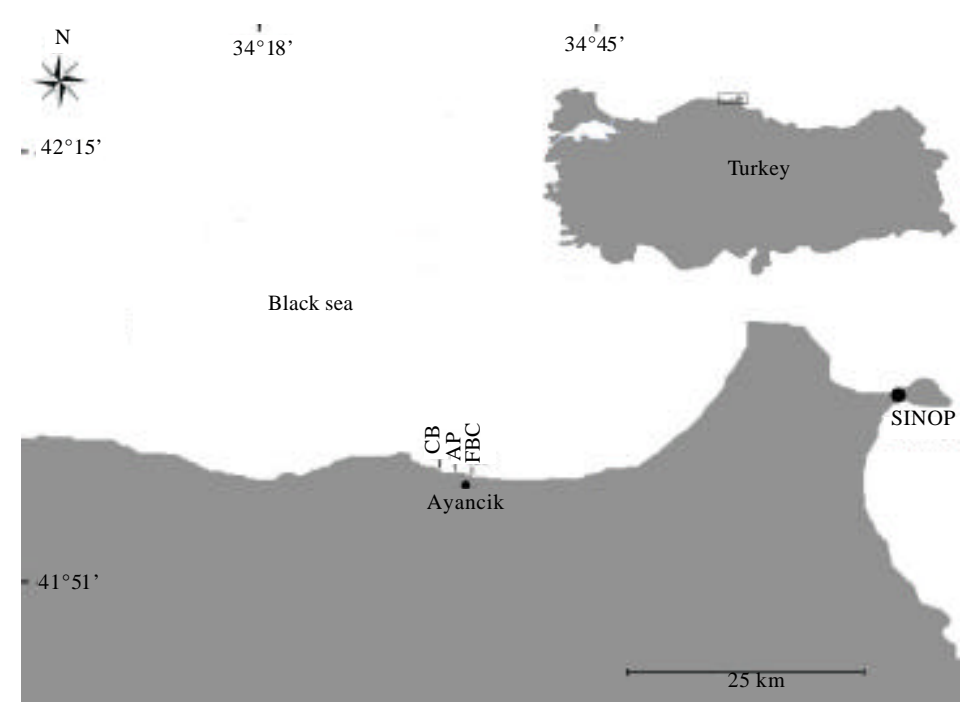

Fig. 1: Map of the study area showing the locations of the three stations (FPC, $\mathrm{AP}$ and $\mathrm{CB}$ )

Clemam (2009) and Sabelli et al. (1990, 1992) were followed. All specimens belonging to bivalves and gastropods are deposited at fisheries faculty of Sinop University.

\section{RESULTS AND DISCUSSION}

This species is characterized by the nature of the shell valves and tubes (internal lining of the borrows which sometimes gets thickened as a tube particularly at the posterior end), pallets (a pair of calcareous organs situated at the posterior end of the animal which is used to plug the entry hole during adverse conditions or when the borer is disturbed) and siphons (Santhakumaran, 2006).

Scientific names: Teredo navalis Linnaeus, 1758 (Mollusca, Bivalvia, Teredinidae).

Synonyms: Calmitas navium L., Teredo novangliae Bartsch, 1922.

Common names: Naval Shipworm (GB), Schiffsbohrwurm (DE), Paeleorm (DK), Laivagrauzis (LT).

- Phylum: Mollusca

- Class: Bivalvia

- Subclass: Heterodonta

- Order: Myoida

- Suborder: Myina

- Superfamily: Pholadoidea

- Family: Teredinidae
Species description: The body of $T$. navalis is reddish and has a characteristic elongated worm-like shape with the anterior part covered by a small reduced helmet-like shell acting as a wood-boring instrument. The protective role of the shells is lost because the animal spends all its life surrounded by wood. Actually the shell consists of two parts with anterior and posterior lobes similar in size. Each shell is triangular in shape and is white with light brown periostracum. The valves of the shell are divided into regions with differing sculptures having breaks situated near the anterior end. The brownish soft worm-like body of the shipworm lies in a calcareous tube up to $60 \mathrm{~cm}$ long and $1 \mathrm{~cm}$ in diameter. The tube is divided by a dividing wall (septa) near the opening. Its only connection with the outer world is a tiny hole that the mollusk uses to protrude its two posterior siphons to keep the flow of water running through its mantle cavity. The siphons can be rapidly withdrawn by the animal and closed off by a calcareous pair of white paddle shaped pallets $0.5 \mathrm{~cm}$ long (Fig. 2). This makes T. navalis hardly detectable from outside of the wood and often the damage shows up only when the piling breaks. Genus, Teredo includes about 20 species inhabiting wooden material of $\operatorname{logs}$, pilings, ships and nearly any other submerged wooden constructions from temperate to tropical zones of the world's oceans (Hayward and Ryland, 1990; Didziulis, 2007).

Habitat: Teredo is a unique genus of marine mollusk species feeding solely on wood (Fig. 3). Symbiotic cellulolytic nitrogen-fixing bacteria are harboured within specialized epithelial cells (bacteriocytes) located within 


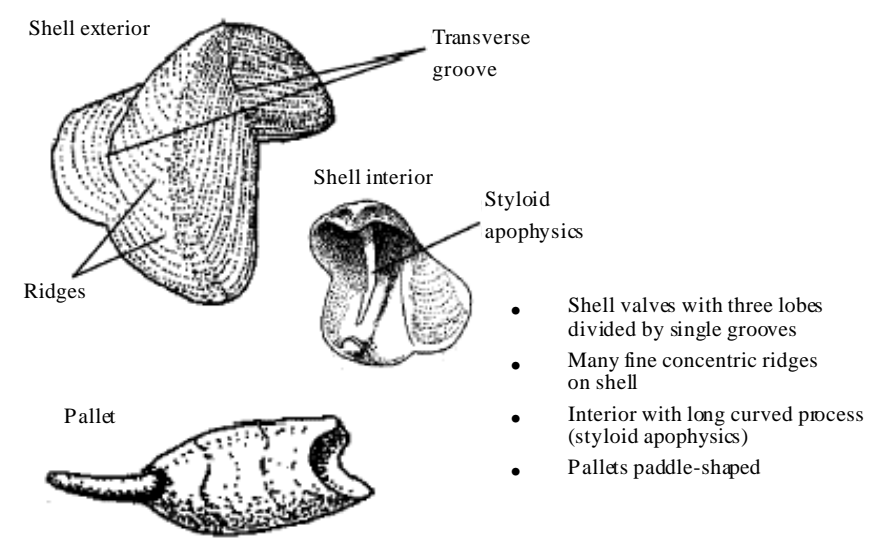

Fig. 2: Diagram belongs to T. navalis Linnaeus, 1758 adapted from Hayward and Ryland (1990) (NIMPIS, 2002)

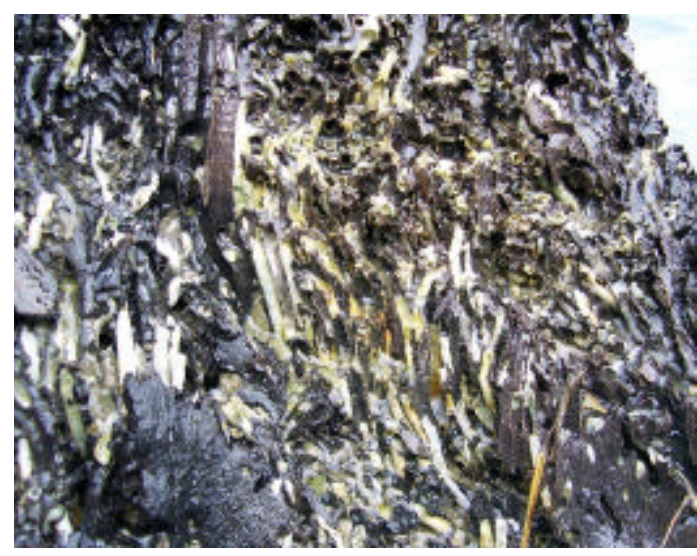

Fig. 3: Pieces of wood heavily damaged by shipworm (Ayancik-Sinop) (Photo by Culha M.)

the gills previously called the gland of Deshayes. However, a more thorough examination of the gland proved that its structure is not a glandular tissue but represents associations of symbiotic bacteria. Enzymes produced by these symbiotic bacteria facilitate digestion of wood and provide an internal source of combined nitrogen. Shipworms play an important ecological role as the principle agents of mineralization of celluloid plant material in shallow marine and brackish environments. The limiting factor for spread is salinity which has to be above $8 \%$ for successful reproduction. Freshwater is deadly to these invertebrates (Didziulis, 2007).

This study was conducted at three region belonging to Sinop coasts in the southern part of the Black Sea, 35 adult specimens of $T$. navalis were encountered. The species was found at the depth of between 0.5 and $5 \mathrm{~m}$ into some old tree roots and old wood pieces on stony-sand bottom. The distribution of this boring organism as habitat was found to be any sort of infested under-water woody materials such as submerged structures, hulls of fishing boats, jetty-piles etc. (Santhakumaran, 2006). The cryptogenic shipworm, Teredo navalis is one of the most effective and harmful marine invaders (Zenetos et al., 2005). Adults naturally spread with floating wooden objects (e.g., drift wood, wooden ship hulls). Larvae are pelagic for approximately two weeks and are dispersed by water currents. Teredenid larvae were found in ballast water samples indicating the likeliness of this dispersal vector. The native range of the species is unclear this is a truly cryptogenic species.

In European waters the species was firstly recorded in 1731 destroying wooden dyke gates in the Netherlands. Today it is found along the British Channel and North Sea coasts. The easternmost border of shipworm settlement in the Baltic is the Island of Rügen, Germany (Daisie, 2009). Teredo navalis is believed by several authorities to be native to the European western Atlantic.

It is a cosmopolitan species found both in Atlantic and Pacific from the tropics and subtropics to cool temperate waters of both the northern and southern hemisphere (Didziulis, 2007). Place of the first registration in the Black Sea of the species was sea of Azov (year of 1953) on submerged woods (Alexandrov and $\mathrm{Yu}, 2000$ ).

\section{CONCLUTION}

In this study, T. navalis L., 1758 was recorded for the first time from the Black Sea coasts of Turkey. The presence of the species in the area could be result in marine transportation. Subsequent more detailed studies are expected to provide further contributions to the understanding of the biodiversity of marine life at Turkey's coasts. 


\section{ACKNOWLEDGMENT}

Researches would like to thank the crew of the $R / V$ Arastirma I of Sinop University, Fisheries Faculty for their kind assistance during the samplings.

\section{REFERENCES}

Alexandrov, B. and Z. Yu, 2000. Chronicle of exotic species introduction into the black sea. Proceedings of the International Symposium on the Black Sea Ecological Problems (BSEP'00), Isbssapi Scseio, Odessa, pp: 14-19.

Clemam, 2009. Unitas malacologica check list of European marine mollusca. http://www.mnhn.fr/base/malaco. html.

Culha, M., G. Erik, S.T. Culha, M.Y. Celik and I. ve Oksuz, 2008. Marine mollusk fauna of kastamonu and sinop provinces (coasts of Ayancik, Türkeli, Çatalzeytin and Abana). Proceedings of the 2nd Malacology Congress, Oct. 8-10, Çukurova University, Fisheries Faculty, Adana, Turkey (Poster presentation).

Daisie, 2009. Delivering alien invasive species inventories for Europe. http://www.europe-aliens .org/speciesFactsheet.do?speciesId $=50276 \#$.

Demir, M., 2003. Shells of mollusk collected from the seas of Turkey. Turk. J. Zool., 27: 101-140.

Didziulis, V., 2007. NOBANIS-invasive alien species fact sheet-Teredo navalis. http://www.nobanis.org/ files/factsheets/Teredo_navalis.pdf.
Hayward, P.J. and J.S. Ryland, 1990. The Marine Fauna of the British Isles and North-West Europe. Vol. 2, Clarendon Press, Oxford, pp: 996.

NIMPIS, 2002. Teredo navalis species summary. National Introduced Marine Pest Information System, Hewitt, C.L., R.B. Martin, C. Sliwa, F.R. McEnnulty, N.E. Murphy, T. Jones and S. Cooper (Eds.). Web Publication. http://crimp.marine.csiro.au/nimpis.

Ozturk, B. and C. Cevik, 2000. Mollusks fauna of Turkish Seas. Club Conchylia Inform., 32: 27-53.

Sabelli, B., R. Giannuzzi-Savelli and D. Bedulli, 1990. Catalogo Annotato dei Molluschi Marini del Mediterraneo. Vol. 1, Libreria Naturalistica Bolognese, Bologna, pp: 348.

Sabelli, B., R. Giannuzzi-Savelli and D. Bedulli, 1992. Catalogo Annotato dei Molluschi Marini del Mediterraneo. Vol. 2, Libreria Naturalistica Bolognese, Bologna, pp: 150.

Santhakumaran, L.N., 2006. Wood-borers: Biodiversity in mangrove ecosystems. Mangroves Training Course, 6th Course, 1-15 June 2006, Centre of Advanced Studies in Marine Biology, Annamalai University, India, pp: 27-35.

Zenetos, A., M.E. Çinar, M.A. Pancucci-Papadopoulou, J.G. Harmelin and G. Furnari et al., 2005. Annotated list of marine alien species in the mediterranean with records of the worst invasive species. Mediterranean Mar. Sci., 6: 63-118. 